\title{
Postcolonial Muslim Women between Faith and Fashion in Habib Selmi's Novel "The Women of al-Basatin"(2010)
}

\author{
Amany A. Alsiefy \\ Department of English Philology, Freie Universtät zu Berlin, Germany \\ Email:abdelraz@zedat.fu-berlin.de
}

\begin{abstract}
This paper traces the widespread wave of fashionable headscarf-wearers (hijabs) in Muslim societies in an attempt to illustrate how the contemporary spirit of consumer culture informs female's self-image and behaviour in the context of post-colonial literature. I am going to do that concerning the voices of the fictional female figures in Habib Al-Selmi's novel "The Women of al-Basatin (2010) Habib Salmi is a renowned Arab writer whose modern Arabic literature explores the relationship/clash between Eastern and Western values.

In this paper, I aim to highlight the meanings attributed to this practice of head-covering as in contemporary consumerist Tunisian society individually, culturally and contextually assigned.
\end{abstract}

Keywords-Consumerism, faith, postcolonial, Tunisia, women.

\section{INTRODUCTION}

Ever since the 19th-century colonialism, the controversy over the representation of Muslim women in the Western literary texts has never lost its momentum among the Western and non-Western intellectuals and feminists writers. In this Western literary texts, the Islamic practice of veiling or "wearing a headscarf" has been used as the main tool to stigmatize all Muslim women as oppressed subordinate ugly looking veiled women vis-à-vis the emancipated fashionable unveiled Western woman, regardless of their geographical place, social context, or educational background.

Many literary critics and postcolonial scholars argue that the afore-mentioned stereotypical Orientalist binary position continued to inform the mainstream representation of Muslim women's identities in most postcolonial literary texts, in particular, literary works that were written and published in the West. Hundreds of contemporary postcolonial fiction and life-narratives used a picture or a drawing of a veiled/head-covered Muslim woman on the cover of as a symbol enough to tell those women's misery and suffering that a reader expects to find even before reading one page of the text work. For instance, Fadia Fakir's novel "My name is Salma"( 2010) that tells the story of a Jordanian girl ( Salma) the Novel's cover depicts a girl wears a loose traditional dress and a black headscarf. Salma's tragedy started when her family found out that she had a sexual relationship outside marriage. Salma was jailed and threatened of killing by her brothers. Salma's salvation was achieved through her flight to Britain, where she first learnt good manners from her landlady and then to led got married to a good Englishman, renouncing her Islamic practices.

The picture of abused Muslim women wearing ugly headscarves on the cover of the literary work was also present in Azhar Nafis's novel " Reading Lolita in Tehran: A Memoir in Books "( 2003). The novel depicts the suffering of the Iranian woman and forcing her to be "enveloped in voluminous fabric"( Nafisi 2003: 51) of the black ugly veil after the "Islamic Revolution" (1979). On the cover of the book, we see two young head-scarf wearers who look down, as an expression of their submission and/or their sad lives.

The aforementioned dominant representation in the West, however, has been challenged by a wave of feminist writers whose aim to privilege Muslim women's experiences in their social and historical environment. In these literary works, the headscarf has also appeared as the most important feature and symbol to defy the mainstream stereotypical representation. Thus, on the cover of these literary texts, we see (women/girls) in modern fashionable attractive dresses and trousers while also wearing head-scarves in various bright colours. Those girls/ women look at the reader with confidence and smiles on their faces. 
Some of these works include for example, "The Girl in the Tangerine Headscarf" (2006) by the Syrian-American poet and writer Mahja Kahaf, and "Does my Head Look Big in This?"( 2005) by the Palestinian Australian writer Randa Abdel Fattah and Sophia Khan is Not Obliged (2016) by the British-Pakistani Aisha Malik.

Although the veil/headscarf has also remained a problematic issue among the secular-oriented and the conservative elite in the Middle East and North Africa, and despite the fact that the headscarf is widely read as of a symbol of the good respectful women in the conservative Arab cultures, the experience of head-scarf wearers is rarely depicted in Arabic literature.

In this context, Habib Selmi novel "Women of al-Basatin" ( 2010) is considered one of the rare and most celebrated fictional work that able not only to dive into the psyche of Muslim women towards wearing the headscarf but also the illuminate the changes and /or challenges that the conservative Arab cultures are facing.

In the following section, I am going to discuss the challenges of choosing to dress fashionably and to consume Western goods in the post-colonial Muslim majority Tunisian society in light of the Al-Habib Al-Salmi's last novel "The Women of al-Basatin" (2010).

\section{FASHIONABLE MUSLIM WOMEN IN HABIB SALMI'S NOVEL "THE WOMEN OF AL- BASATIN"}

Habib Salmi is one of the most important Arab writers, whose fiction depicts the relationship/clash between Eastern and Western values and practices. Selmi was born in Kairouan, Tunisia, in 1951 and is a university lecturer of Arabic literature in Paris since 1983.

Many of his novels have been translated into several foreign languages (English, French, German and Italian). His novel "The Fragrances of Marie Claire" (2008) and "Women of alBasatin" (2010) were selected for the Arab Poker Award in (2009) and (2012), respectively.

In his novel, " Women of al-Basatin" - like many of his works - Salmi delves into the psychology and consciousness of the Tunisian personality on the one hand and dismantles the stereotype of Eastern and Western society on the other.

"The Women of al-Basatin" is originally written in Arabic and was widely read in the Arab world. It discusses Tunisians' ambivalent attitude towards consumer modernity in a socially conservative society by following the story of three female characters who struggle to negotiate their individuality, freedom, and modernity.
From the very beginning, the reader is introduced to a confusing scene that challenges his/her view about an Arab society.

On the cover of the novel, we are defied by women in different dressing styles. One can see some women wear black loose dresses and cover their head and faces, as well as fashionable girls who wear headscarves while strands of their hair are revealed. In the middle of the picture, one can see women wear short attractive dresses. Moreover, unlike the mainstream feminist postcolonial text, one is not able to detect the general condition and status of those Tunisian women. In the picture, some women are smiling while engaged in talking with each other, others look into the void and some look confidently at the reader.

The plot is built mainly around the three female character's choice of their clothing styles in the claimed liberal modern society that is rooted in conservative Islamic culture.

The novel is set in in a middle-class neighbourhood called "al-Basatin", near Al-Habib Bourguiba's Street in the contemporary Tunisian capital city Tunis and told from history and geography teacher Tawfiq's subjective perspective. The narrator recounts his vacation with his family in Tunis after being for five years in France.

The novel starts by describing the protagonist reunion with his brother, Ibrahim, Ibrahim's wife Yusra and their child. He tells the reader of changes that occurred on the female character's behaviour after her own decision to wear a headscarf the (hijab). Tawfiq says, "Ibrahim gives me a long and warm hug. He is the closest of all my brothers to me since I am only one year older than him. As for his wife, Yusra, she does not kiss me as she used to. She stretches out her hand while bending back her back. She hardly shakes me. I was not able to understand her strange behaviour until Ibrahim bent and said 'Look Yusra wears a hijab': he adds 'She decided to wear it. I do not have anything to do with her decision" (Salmi 2010:6, my translation).

In this scene, before I begin to read Yusra's new behaviour coupled with her wearing the hijab, I will begin by referring to the influence of Orientalist discourse on the (Eastern / Muslim) person himself through Yusra's husband comment on her decision to wear the head scarf. This scene can be interpreted as a reflection of the self of the dominant" Orientalist " discourse" even in the Arab cultures. Yursa's Husband tries to defend himself and prove his innocence from a stigma that no one has accused him He says: "She decided to wear it. I do not have anything to do with her decision"( p.6). 
Besides, in this scene, one can read the transformation that the clothing style pinged on Yusra's attitude towards males in light of Emma Tarlo's argument in her book "Visibly Muslim Fashion, Politics, Faith" (2010). In her anthropological study on the meaning of the Islamic practice of hijab in contemporary London, she maintains that the contemporary head-scarf, in its modern styles, brings to the forefront the agency of the religious practice in the making of the self. She affirms that "for many women, the adoption of hijab transforms not only their sense of self but also their relationship to others and the wider environment". This also underlines "the agency of hijab in people's lives" (Tarlo 2010, 132). Here, according to Taylor, the real and imagined impact of the head-scarves matches what Alfred Gell describes as a secondary agency of objects, that is, "the capacity of artefacts which are the products of human agency to take on an agency in the lives of humans" (Tarlo 2010: 151).

In contrast, Tawfiq goes on to describe Yusra's admiration of the French fashion despite wearing the hijab when he gives her a revealing short-sleeves silk blouse, which he brought from France.

He says, "I breathe a sigh of relief when Yusra is impressed with her gift which is a silk blouse. I asked Catherine to buy her an excellent quality outfit, but I did not know she started wearing a hijab. The blouse was short-sleeved and transparent at the bosom" (ibid: 10)

Yusra likes the blouse while her husband, Ibrahim, is surprised that his wife could wear such a blouse despite wearing a hijab that required loose modest dresses.

Ibrahim says," You wear a hijab and such a blouse too?" Yusra replies laughing, "What is the wrong with that? I will wear it when where are alone at home. And when I go out I can wear the safari above it."

Ibrahim replies, "Such a blouse has to be seen by other people or else what the meaning of buying it" (Al-Salmi 2010: 11).

Ibrahim goes on to comment on the form of the fashion adopted in contemporary Tunisian society saying: "Now in Tunisia, you find everything with the hijab."

Yusra looks at him and asks what do you mean?

Ibrahim replies:" I mean the Tunisian woman wears a hijab, but she does not abandon tight-fitting jeans".

Yusra: Why do you want her to abandon the jeans? ... What is important for her to wear a loose garment?

Ibrahim: And what about the mini?
Yusra: What is the difference between the mini and the jeans? What is required for a woman is to be covered when unrelated men are around her.

Ibrahim adds sarcastically: The story does not stop at this point ... I heard that some head-covered women wear a skinny-leggings.

Yusra bursts into loud laughter and Ibrahim joined her saying: Imagine... Hijab on their heads and skinny on their hips!

Yusra: God forgives everyone... He is merciful. (Al-Salmi 2010: 11- 12).

In another scene towards the end of the novel, Yusra wears the French blouse under her loose dress while wearing makeup. Her husband exclaims how she wears such extravagant makeup while she prays and wears a hijab. Nonetheless, it seems clear that Yusra not only does not see any contradiction in that, but she does not consider it against her Islamic values. Tawfiq describes this scene in the following lines.

"I noticed that Yusra wears eyeliner and a glow of light red lipstick, and plucked her eyebrows... What caught my attention was that she was wearing the blouse I bought for her under a loose dress... Maybe she wanted to show me, at the end of the last day of vacation that she was happy with the gift? But her makeup in such a way means that she has not changed despite wearing the hijab and that it is still taking care of its external appearance.

Ibrahim surprisingly asks her: "You pray ... and wear a hijab ... and you get to wear makeup like this?"

Yusra replies, "What is the problem?" Is makeup haram (prohibited in Arabic)? (Ibid: 202).

Near the end of the novel, the narrator describes the scene of his farewell by his family. Yusra gives him spices and olive oil, reminds him of what they wish he would buy for them and from France next visit.

"They all stand up to bid farewell. Yusra hands me a box of spices and a bottle of olive oil. And then recommends that I pay attention to the sizes when he buys clothes for their son, Wael, next time. She also does forget to tell me that she still dreams of buying her a coat that I also watched on television... Ibrahim reminds me once again of the need to come in the summer for my next visit, before telling me to bring him a more modern mobile phone from France than his current old one (ibid: 206).

In the aforementioned quotation, Al- Salmi rivets the reader's attention to Muslim women's new attitude towards the consumer culture and Western fashion as well as Western products. Muslim Tunisian women who are triggered by the 
tide of the conservative wave coming from the Middle East are also obsessed with the image of beauty, makeup, and fashionable dresses similar to Western fashion coming to them from the West. All this despite being observant Muslims.

Even though it could be read as resisting Muslim men's conservative attitude towards women's appearance, this tendency of a wave of head-scarf wearers to combine beauty, fashion, and the hijab may devoid religion from it an essential aspect - spirituality. This led Rania Lewis to describe their attitude as "fake modesty" in her book Modest Fashion: Styling Bodies, Mediating Faith (2013).

Fadwa El Guindi is one of the few women who studied the history of the hijab and its meaning in the post-colonial modern era. She illustrates the importance of wearing the hijab in light of different perceptions of privacy in Islamic culture and other religions. According to El Guindi, privacy is, "the need for individuals, families or other social groups, to separate themselves from others at various times, for certain well-defined activities." She goes on to state that Islam designates a private space for sexuality, and therefore the public space has been "desexualized" (Cf. Cotton, 31-32). This is the role of the hijab on women's head-scarves. A Tunisian girl supports this argument stating, "When I wear a hijab, men in the street leave me alone. The Hijab gives a message to men. It tells them that a woman is not sexually available" (Charrad 2001, 67). Here, El Guindi argues that covering the head enables Muslim women to transform public space into a private non-sexual space, and differs from the Western societies that divide spaces into the profane public and the sacred domestic realm.

In this vein, many devout Muslim women argue that their modest Islamic dress code liberates them from men's gazes, and "saves women from the ravages of the beauty game". Yusufali argues that to win in the beauty game, women endeavour to make "themselves into the images of beautiful women that they see all around them". Unlike the choice of a group of women to wear the hijab, they feel that they are saved from the "bondage of the swinging pendulum of the fashion industry and other institutions that exploit females" (Yusufali). Thus, Mustapha and Yusufali consider the hijab as a method that enables women to avoid "the commodification/objectification trap," and it offers them a way to retain their own true "personhood"(Bullock 2010,2021) without sacrificing their rights to equality in the public sphere.

The aforementioned argument, however, contradicts the prevailing contemporary fashion dress-code in post-colonial society today. Despite wearing the hijab and covering their hair, necks, and sometimes their face, the present so-called "Islamic dress" differs in its form and designs and is also read as a contradiction to the modest non-sexual dress called for by Quran and Sunna. Despite their belief in the divine verses that required inner and external modesty, contemporary consumer culture and the obsession with novelty and change were able to challenge all the traditional mainstream patriarchal interpretations.

\section{POSTCOLONIAL FASHIONABLE DRESS'S DOUBLE CRITIQUE}

Seen from a post-colonial feminist perspective, the depiction of Yusra as a representation of a Muslim women, one can argue that she adopts the concept of the strategy of a double critique, namely challenging both patriarchal interpretations of qur'anic verses as well as resisting the Western Orientalist image of Muslim women as invisible and hidden. Here fashionable Muslim women endeavour to accommodate both the modern secular consumerist lifestyle and their Islamic values, representing what Meriam Cook called a "double agent". They attack both the colonizer and colonized at the same time, while "asserting and also balancing multiple overlapping and sometimes contradictory allegiances" (Cooke 2000:107).

The narrator, however, challenges the prevailing western reader's narrative on forcing Muslim women to wear headcovers by their jealous conservative Muslim men. He says:

"He (Ibrahim) adds as if he is trying to prove his innocence from a very serious crime 'She decided to wear it. I do not have anything to do with her decision" (Al-Salmi 2010:6). Also, Ibrahim's words could be read as a sign of the dominance of the colonial discourse on such practices -called "self-Orientalistiation", namely that a range of Muslims themselves believed in the Orientalist discourse that all Muslim women are forced by their male kens to cover their hair.

Nonetheless, one can understand Yusra's choice of wearing the hijab without discarding her desire to be "in style" in light of the poststructuralist understanding of the individual's agency in a given culture. According to poststructuralists, "human subjectivity is constructed by ideology (Althusser), language (Lacan) or discourse (Foucault), [therefore] any action performed by that subject must be also to some extent a consequence of those things" (Ashcroft, Griffiths and Tiffin 8). In this vein, in agreement with the poststructuralist understanding of liberal agency, Charles Tylor read religious actions in a given conservative community regarding what he 
refers to as the "community's good". Tyler maintains that each identity tends to imagine itself in a certain social community. It aims to be "Embedding socially", namely this identity's choices are determined concerning and within the norms and conventions of the social environment (Tylor 1998: 147-150).

Nonetheless, one can read these "fashionable "headscarf wearers in the light of Homi Bhabha's theory of hybrid postcolonial identity in his seminal collection of essays, "The Location of Culture" (1994). According to Bhabha, due to the encounter between the Eastern and Western cultures, the postcolonial emergent hybrid identity is situated in a state in between the colonized (Eastern) and the colonizer (Western). He calls this state of "in-between third space", namely it is "in-between subject-positions that are lauded as the local of the disruption and displacement of hegemonic colonial narratives of cultural structures and practices" (Lindsay, 1997).

According to Bhabha, the third space guarantees them to represent a counter-hegemonic agency; since the hybrid identity can maintain a third space of "recalculating of negotiation" when the colonizer attempts to impose his hegemonic practice (Bhabha, 1996). This third space is a new vista for the emergent of cultural identity. Rutherford underscores this point. He writes "For me, the importance of hybridity is not to be able to trace two original moments from which the third emerges, rather hybridity to me is the "Third Space', which enables other positions to emerge" (Rutherford 1990:211).

All in all, this what lead us to argue that the aforementioned emergent multifaceted identity of Muslim women can offer the possibility of repositioning and empowering the marginal voice within the two oppositional mainstream discourses.

\section{LIMITED "EMANCIPATION"}

According to the patriarchal social norms of the Arab culture, the reputation of the family and even the community is bound by women's behaviour and interactions. According to these social norms, the interaction between unrelated men and women is illicit in Islam and is socially unaccepted. Although these social norms have been transgressed by men, women are required not to violate their prescribed relationship with the unrelated at any cost. Nonetheless, this post-colonial society like other Arab societies, adopted the modern Western consumer culture, and appreciate possessing Western products.

We will see this argument clearer in the depiction of the characters of Laila and Naima who chose not to cover their hair and to wear tight-fitting dresses. In chapter 14, Laila describes her frustration in such a conservative social environment, saying, "These countries are for men only...a woman cannot live here. She cannot even dress the way she wants. And even if she does, they will describe her like a whore. Tunisians are bragging that the Tunisian woman is an emancipated woman who could enjoy rights that no other woman in the Arab world has... But no one of them respects these rights" (Al-Salmi 2010: 137-138).

Here, one can easily detect how an Arab society that is indulged in Western goods and devices, as well as the, claimed most liberal atmosphere for women in the Arab world is not ready to tolerate the free choices of females like Laila for her Western dress-code. She is criticized by people around her, and even her family, for her tight-fitting, short, revealing dresses as not a proper dress for a Tunisian woman. Also, in the last chapter, the reader is shocked by the tragic destiny of Naima, who was taken to custody because of an accusation that she was living with a distant male relative. Naima is an outstanding example of an appreciation of the individual's appearance in Arab society. As a divorced woman, she tried hard to gain the respect of her social environment by wearing a hijab but failed when she took it off. Naima's dilemma, like Laila, was that accepting her socially was connected mainly to her external appearance - in particular wearing the hijab. The practice of head-covering was women's card of gaining respect even with wearing makeup and tight-fitting attractive trousers, skirts or dresses. Nonetheless, read from a post-colonial perspective, what is striking in Al-Salmi's narrative is the feminist female characters' different attitude towards Western fashion and Islamic dress-code in their contemporary post-colonial society. One can argue that this portrayal challenges challenge the orientalist, mainstream postcolonial discourse that reads Muslim women as a monolithic category. Moreover, the three women are not "passive" subordinate women as a part of "Othering" Muslims, and their need for Western outsiders to liberate them. Nevertheless, argue the depiction of the tragic ending of Naima and Leila's frustration is a stereotypical representation of an Arab Muslim woman who saw her liberation only in Western liberal societies. In this respect, this means that the agency of fashionable headscarf wearers in this conservative culture while it can subvert and challenge both Orientalist and Islamist patriarchal attitude towards women -can also imply that those women assert themselves only within a certain prescribed role, while not allowed to step beyond them. 
Yet, on the other hand, for some scholars, those modern fashionable Muslim women fell prey to the clutches of consumerism and idealizing the image of a modern beautiful female through combining both the headscarves or chadors and heels and make-up.

Here, Mernissi discusses the dilemma of women in the contemporary modern capitalist Western society. She argues that while women are granted access to the public sphere, which is denied in the Muslim world of women, they are not entirely free from males' domination, rather, they are controlled by the concept of beauty in the public sphere where men define their size, age, and makeup. This led Mernissi to claim that women in the West are also dictated by men's power, even if the result of men's power is different due to different interests. In her autobiography "Scheherazade Goes West: Different Cultures, Different Harems"( 2002) Mernissi writes, "To be considered beautiful on the European side of the Mediterranean is to dress as the market- Imam demands"... in the accident, men dominate women by unveiling what beauty ought to be. If you don't look like the picture they unveil, you are doomed "(Mernissi 2002: 114,112).

Interestingly enough, headscarf wearers' contemporary attitude towards fashion and consumer culture broke the borders between the aforementioned dichotomy models. Therefore, in the context of Muslim women, we are faced with the following question

1: To what extent can we talk of Muslim women's resistance and liberation from male domination in Muslim societies, with reference specifically to the new wave of the so-called fashionable "Islamic dress"?

\section{CONCLUSION}

Throughout history, societies have their clothing style to pass from one generation to another without significant changes. In Muslims cultures until the nineteenth century, Muslim women used to wear loose robes and head-wear with different colours and materials according to geographical place and social class but colonialism, travel, and the tide of globalization were all able to defuse the Western consumer culture around the world, and break down the rigid borders between the modern secular fashionable dress and modest religious clothing styles. This can be seen in a widespread wave of young Muslim women's desire to wear a fashionable dress and be "in style" (Abaza, 2007; Hansen, 2004; Jones, 2007; Moors, 2007). Those Muslim women opted for covering their heads and necks as a symbol of their religious Islamic identity. Nonetheless, they are dressed in fashionable headwear as well as sexy attractive dresses that contradict the claimed required modesty. In this paper, I attempted to read Muslim women's contemporary attitude towards Muslim identity, wearing hijab and fashion in light of Al-Salmi's novel "The Women of al- Basatin" to show the difficulty of being fashionable and Muslim in a conservative society, and how women endeavour to reconcile their Islamic value in a modern consumer age.

Those Muslim women's involvement in the contemporary western consuming culture invites us to question the nature of a kind of present Muslim woman's consciousness and conviction.

\section{ACKNOWLEDGEMENTS}

I would like to acknowledge Dr Hassan Rabhi at the University of Gafsa. Tunisia, as the second reader of this paper, and I am gratefully indebted to his very valuable comments on this paper.

\section{REFERENCES}

[1] Akou, H. M. (2007). Building a New "World-Fashion": Islamic Dress in the Twenty-First Century. Fashion Theory, 11 (4), 403-421.

[2] Alcoff, L. M., M. R. Hames-Garcia, S.P. Mohanty, P. M. Moya, eds. Identity politics reconsidered. New York, Palgrave Macmillan.2006.

[3] Balasescu, A. 'Teheran chic, Islamic headscarves, fashion designers and new geographies of modernity', Fashion Theory, 7 (1), 39-56. 2003

[4] Baliamoune-Lutz, M (2009a). Tunisia's Development Experience: A Success Story? 'UNUWIDER Research Paper No. 2009/32.

[5] Baudelaire, C., Modern Hayatın Ressamı, İletişim Yayınları 954, 2004.

[6] Bhabha, Homi. The Location of Culture. New York: Routledge.1994.

[7] _ The Third Space: Interview with Homi Bhabha. Identity, Community, Culture, Difference. Ed Rutherford, J. London: Lawrence \& Wishart. 1990.

[8] Braudel, F, The Structures of Everyday Life: Civilization and Capitalism, 15th-18th Century, Vol.1, HarperCollins Publishers, 1985.

[9] Boubekeur, Amel. "Cool and Competitive: Muslim Culture in the West", ISIM Review 16, 2005 autumn, Charrad, M. M. "Tunisia at the Forefront of the Arab-World: Two major Waves of Gender Legislation". Washington and Lee Law. Review.64.4. (2000): 1513 -1527.

[10] Cooke, M. (2000). "Multiple Critique: Islamic Feminist Rhetorical Strategies."

[11] Nepantla: Views from South 1(1): 91-110. 
[12] Cooke, Miriam. Women Claim Islam. London; New York: Routledge. 2001.

[13] Cotton. Jennifer. Forced Feminism: Women, Hijab, and the One- Party State in Post-Colonial Tunisia. Thesis. Georgia State University. Print. 2006.

[14] Davis, F. (1992), Fashion, Culture and Identity, Chicago: University of Chicago Press.

[15] Douglas, Mary, and Baron Isherwood. The World of Goods: Toward an Anthropology of Consumption. 2nd ed. (London and New York: Routledge.1996.

[16] Eum, Ikran. (2009). "A Study on Islamic Consumerism from a Cultural Perspective: Intensification of Muslim Identity and its Impact on the Emerging Muslim Market." International Area Studies Review. V.12 (2) Fall 2009. P. 1-19

[17] Hall. S. "Introduction: who needs an identity?" In Questions of Cultural Identity, edited by P. Du Gay and S. Hall. London, Sage.1996.

[18] Khan, Uthman \& Introduction. Islamic Clothing, Then and Now. 2014.

[19] Lazreg, Marnia. "Feminism and Difference: The Perils of Writing as a Woman on Women in Algeria", Feminist Studies, 14, 1 (1988).

[20] Lewis, R. (2013). Modest Fashion: Styling Bodies, Mediating Faith. New York, NY. 2013.

[21] Lindsay, E. "Here and There? Hybridity in a Multicultural Australia." Science and Society, Murdoch University, Institute for Science and Technology Policy, School of Social Sciences and Psychology. Murdoch University.1997.

[22] Lipovetsky, G., the Empire of Fashion, Princeton University Press, 1994.

[23] Mahmood, S. Politics of Piety: The Islamic Revival and the Feminist Subject. Princeton.2005.

[24] McCracken, G. (1988), Culture and Consumption, Bloomington, IN University Press.

[25] Cooke, Miriam "Multiple Critique: Islamic Feminist Rhetorical Strategies," in Postcolonialism, Feminism, and Religious Discourse, ed. Laura E. Donaldson and Kwok PuiLan (New York: Routledge, 2001), 142-60.

[26] McCracken, Grant. Culture and Consumption: New Approaches to the Symbolic Character of Consumer Goods and Activities. (Bloomington and

[27] Indianapolis: Indiana University Press, 1990).

[28] Mernissi, Fatima. Scheherazade Goes West: Different Cultures, Different Harems. New York: Washington Square Press 2002.

[29] Nystrom, P., Economics of Fashion, New York: Ronald Press Company, 1928.

[30] Rocamora, Agnes \& Smelik Thinking Through Fashion:" A Guide to Key Theorist: An Introduction" in Thinking Through Fashion: A Guide to Key Theorists. Ed. Rocamora, Agnes \& Smelik. Verlag. 2015. Pp.1-27.

[31] Rutherford, J. The Third Space: Interview with Homi Bhabha. Identity, Community, Culture, Difference. London.1990.
[32] Salmi, Habib. The Women of al-Basatin Dar Al.Adab: Beirut. 2010.

[33] Smaoui, Fatma \& Ghariani, Ghofrane. Being fashionable in today's Tunisia: What about cultural identity? in "Handbook of Islamic Marketing", Ed. Özlem Sandikci, Gillian Rice. 2011. P. 77-113.

[34] Tarlo. Emma. Visibly Muslim: Fashion, Politics, Faith. Oxford: Bloomsbury Academic, 2010.

[35] Triaud, Jean-Louis. "Islam in Africa under French Colonial Rule". The History of Islam in Africa.Ed. Nehemia Levtzion and Randall Pouwels. Athens, $\mathrm{OH}$ : Ohio University Press.2000, 153-168.

[36] Sobh, Rana\& Belk, Russel \& Gressel, Justin (2014) Mimicry and modernity in the Middle East: fashion invisibility and young women of the Arab Gulf, Consumption Markets \& Culture, 17:4, 392-412, DOI: 10.1080/10253866.2013.865166

[37] Stearns, Peter N. Consumerism in World History: The Global Transformation of Desire. London and New York: Routledge, 2001.

[38] Yegenoglu, Meyda. "Sartorial Fabrications: Enlightenment and Western Feminism", in Laura E. Donaldson and Kwok Puilan [eds.], Postcolonialism, Feminism, and Religious Discourse [New York and London: Routledge, 2002], Pp.8299.

[39] Williams, Raymond. Keywords: A Vocabulary of Culture and Society. (London:1976). 